Volume 2 Nomor 2 Tahun 2020

e-ISSN: 2655-948X

http://u.lipi.go.id/1548306171

\title{
PENERAPAN METODE PENUGASAN BERVARIATIF DAN UMPAN BALIK PADA MATERI MUNAKAHAT / PERNIKAHAN DALAM MENINGKATKAN KEAKTIFAN BELAJAR SISWA KELAS XII-TPM-A SMKN 2 SURAKARTA SEMESTER GASAL TAHUN PELAJARAN 2020/2021 DI MASA COVID-19
}

\author{
Sri Handayani \\ SMK Negeri 2 Surakarta \\ e-mail: srihandayanismk2@gmail.com
}

Diterima: 23 November 2020 | Direvisi: 24 November 2020 | Disetujui: 27 November 2020

(C) 2018 Program Studi Pendidikan Agama Islam Fakultas Agama Islam Universitas Islam Malang

\begin{abstract}
The Covid-19 pandemic demands that teachers be more creative and innovative in determining learning methods, especially in Islamic Religious Education subjects. Teaching religion with abstract nuances of material is not easy for students to grasp the teacher's explanation, especially on Munakahat material. As found in SMKN 2 Surakarta, this study aims to reveal the results of varied methods and feedback on the results of teacher creativity in increasing learning activeness during the pandemic. This research was conducted in class XII TPM-A Odd Semester material Munakahat. The research method used is Classroom Action Research with two cycles, where each cycle consists of planning, implementing actions, reflection and evaluation. Analysis of the data used through qualitative descriptive analysis based on the results of observations, interviews, and reflections in cycle I and cycle II. The results of this study indicate that the use of varied assignment learning methods and giving feedback can increase the learning activeness of PAI class XII TPM-A students during the Pandemic.
\end{abstract}

Keywords: varied assignments, feedback, learning activeness

\begin{abstract}
Abstrak
Pandemi Covid-19 menuntut guru lebih kreatif dan inovatif dalam menentukan metode pembelajaran khususnya pada mata pelajaran Pendidikan Agama Islam. Mengajarkan agama dengan nuansa materi yang bersifat abstrak tidak mudah bagi siswa menangkap penjelasan guru, terutama pada materi Munakahat. Sebagaimana yang terdapat di SMKN 2 Surakarta, dalam penelitian ini bertujuan untuk mengungkap hasil metode variatif dan umpan balik atas hasil kreatifitas guru dalam meningkatkan keaktifan belajar di masa pandemi. Penelitian ini dilakukan pada siswa kelas XII TPM-A Semester Gasal materi Munakahat. Metode penelitian yang digunakan adalah Penelitian Tindakan Kelas dengan dua siklus, dimana setiap siklus
\end{abstract}

This work is licensed under Creative Commons Attribution Non Commercial 4.0 International License Available online on: http://riset.unisma.ac.id/index.php/fai/index 
terdiri atas perencanaan, pelaksanaan tindakan, refleksi dan evaluasi. Analisis data yang digunakan melalui analisis deskritif kualitatif berdasarkan hasil observasi, wawancara, dan refleksi pada siklus I dan siklus II. Hasil penelitian ini menunjukkan bahwa penggunaan metode pembelajaran penugasan bervariatif dan pemberian umpan balik dapat meningkatkan keaktifan belajar PAI siswa kelas XII TPM-A di masa Pandemi.

Kata Kunci: penugasan bervariatif, umpan balik, keaktifan belajar

\section{Pendahuluan}

Usaha mengatasi dampak COVID-19 pemerintah mengambil tindakan melalui larang kontak fisik maupun kontak sosial antar individu dengan individu lain yang berdampak pada larangan masuk sekolah dan diganti dengan Belajar Dari Rumah (BDR) melalui ragam inovasi dan kreatifitias yang dihasilkan oleh guru dan lembaga. COVID-19 sebagai bencana Nasional non alam memaksa guru dan lembaga untuk lebih teliti dalam memilih penggunaan metode maupun strategi pembelajaran, mengingat model pembelajaran melalui Daring (dalam jaringan online) yang tidak semua siswa mendapatkan kemudahan menerima materi yang disampaikan guru.

Dalam situasi darurat, merujuk pada Peraturan Menteri pendidikan dan Kebudayaan (Permendikbud) nomor 72 Tahun 2013 tentang Penyelenggaraan Pendidikan Layanan Khusus dan sesuai Peraturan Menteri Pendidikan Kebudayaan (Permendikbud) nomor 33 tahun 2019 tentang Penyelengaraan Satuan pendidikan Aman Bencana (SPAB, dalam kondisi darurat pendidikan harus tetap berlangsung melalui akses dan layanan alternatif pendidikan yang pelaksanaanya sesuai kondisi dengan berpusat pada pemenuhan hak pendidikan anak. Sampai saat ini pemerintah provinsi Jawa Tengah dan Pemerintah kota Surakarta telah menerapkan kebijakan pendidikan selama masa darurat, yakni kebijakan BDR (Belajar Dari Rumah).

Demikian halnya di SMK Negeri 2 Surakarta, agar tetap dapat menjalankan proses pembelajaran pembelajaran jarak jauh (Learning distance) mengambil kebijakan yaitu Pembelajaran jarak Jauh Terpadu yaitu perpaduan antara pembelajaran Daring (dalam jaringan) dan Luring (luar jaringan). Pembelajaran daring (online) dilakukan dengan memanfaatkan aplikasi WhatssApp grup (WAG) dan menggunakan google form, sedangkan untuk pembelajaran Luring (offline) memanfaatkan modul untuk memberikan materi atau penugasan proyek, hal ini sesuai dengan Surat Edaran Dinas Pendidikan dan juga Bupati agar tidak memberatkan peserta didik, karena pembelajaran jarak jauh maka hampir tidak ada kegiatan tatap muka dalam proses belajarnya, mulai dari penyampain materi, 
penugasan hingga penilaian. Hal ini sesuai dengan Surat Keputusan Bersama 4 Kemeneterian (Pendidikan, Agama, Kesehatan, dan Dalam Negeri) tentang Panduan Penyelenggaraan Pembelajaran Tahun Ajaran 2020/2021 di Masa Pandemi Corona Virus Disease 2019 (Covid-19).

Secara umum, kendala yang dihadapi di lapangan selama Pembelajaran Jarak Jauh (PJJ) ini cukup banyak dan tidaklah ringan terutama pada pada diri siswa, orang maupun guru sendiri. Kendala terberat yang dihadapi siswa adalah rasa kejenuhan belajar akibat banyaknya tugas yang menumpuk dan harus selesai, sementara kendala pada diri orang tua atau wali siswa adalah tidak semua orang tua bisa setiap saat mendampingi putra-putrinya dalam belajar dan kendala pada guru dalam melaksanakan PJJ ini adalah sulitnya komunikasi dengan orang tua. Demikan halnya pada pembelajaran Agama Islam khususnya pada kelas XII TPM-A, tidak adanya tatap muka ini menyebabkan siswa menjadi bosan dan tidak aktif dalam pembelajaran dan akibatnya hasil pembelajaran menjadi tidak bermakana. Harus disadari dalam pendidikan agama harus mencetak karakter peserta didik yang baik, maka perlu adanya tatap muka dan sentuhan langsung teladan dari seorang pendidik (Safi'i, 2017: 23).

Dalam menghadapi situasi darurat PJJ ini guru Agama berusaha memenuhi kewajiban pembelajaran agar siswa tetap mendapat hak pemenuhan layanan pendidikan selama COVID -19 dengan berprinsip pada pembelajaran jarak jauh dan supaya menghasilkan pengalaman bermakna bagi siswa, maka guru menerapkan metode penugasan bervariatif dan pemberian umpan balik kepada siswa untuk meningkatkan keaktifan belajar siswa.

Metode penugasan adalah cara memberikan tugas dalam bentuk penyusunan laporan dari hasil pembelajarannya. Tujuan metode tersebut atau dikenal dengan sebutan resitasi adalah menghasilkan proses pembelajaran bermakna dan terintegrasi atas kegiatan latihan dan pengalaman yang dilakukannya. Mengapa demikian, karena siswa sedang terlibat atau mengalami proses yang berbeda antara mendengar degan menuangkan hasil pendengarannya dalam bentuk penugasan. Ada proses yang dilakukan melalui metode penugasan dan kelebihannya adalah menjadikan pembelajaran menyenangkan, efektif, dan efisisen.

Umpan balik sangat diperlukan dalam proses pembelajaran hal ini karena umpan balik (feedback) merupakan kesenjangan antara pemahaman dengan informasi yang disampaikan, serta tindak lanjutnya. Pentingnya umpan balik dengan ragam manfaat dalam pembelajaran, yaitu: motivasi peningkatan usaha, dorogan untuk mengabaikan perbedaan hasil dan target capaian; memberi solusi alternatif untuk memahami materi; mengkonfirmasi kebenaran dan kesalahan 
siswa, atau seberapa jauh mereka telah mencapai tujuan; Informasi lebih banyak tersedia atau dibutuhkan; memberi petunjuk arah yang ditempuh siswa; berorientasi pada restrukturisasi pemahaman dan tentu saja membangun keberlanjutan belajar sesuai dengan pendekatan belajar 5 M (Memanusiakan hubungan, memahami konsep, membangun keberlanjutan, memilih tantangan dan memberdayakan konteks), lalu bagaimanakah penggunaan metode penugasan bervariatif dan umpan balik (feedback) dapat meningkatkan keaktifan belajar siswa dalam pembelajaran PAI ?.

Tujuan tindakan ini adalah untuk meningkatkan keaktifan belajar siswa dalam proses pembelajaran PAI di masa pandemic COVID-19 pada siswa kelas XII TPM-A Semester gasal SMK Negeri 2 Surakarta tahun pelajaran 2020/ 2021. Manfaat dari tindakan ini diharapkan mampu memberikan sumbangan terhadap Pembelajaran Jarak Jauh PAI di masa darurat pandemi COVID-19, utamanya untuk upaya meningkatkan keaktifan belajar siswa, dapat memberikan informasi tentang pentingnya keaktifan dalam Pembelajaran Jarak Jauh (PJJ), dapat digunakan sebagai masukan dalam memperluas pengetahuan dan wawasan tentang model pembelajaran dan umpan balik (feedback) terutama dalam rangka meningkatkan keaktifan belajar siswa dalam Pembelajaran Jarak Jauh khususnya pada mata pelajaran PAI.

\section{Kegiatan Belajar Mengajar selama PJJ}

Kegiatan belajar mengajar selama PJJ di masa darurat Pandemi COVID -19 merupakan satu kesatuan dari dua kegiatan searah yang dilakukan secara jarak jauh baik melalui daring (online) maupun Luring (offline). Kegiatan belajar adalah kegiatan utama dalam proses pembelajaran. Sedangkan kegiatan mengajar adalah kegiatan kedua agar terjadinya proses pembelajaran yang optimal (Moedjiono, 1993: 1). Idealnya tujuan pembelajaran yaitu agar murid menguasai seluruh bahan/materi pelajaran (Sukmadinata, 2002).

Pembelajaran Jarak Jauh terpadu (secara daring dan luring) adalah usaha menciptakan sistem lingkungan pembelajaran secara tidak langsung berdasarkan tempat yang berbeda-beda. Sistem lingkungan ini terdiri atas komponen yang saling terkait, diantaranya: tercapainya tujun pengajaran, memberikan materi ringkasan pada pembelajaran, dalam hubungan sosial tertenu memainkan peran guru dan siswa, tersedianya sarana dan prasarana serta jenis kegiatan belajar.

Prinsip pembelajaran Daring diantaranya: pertama, tidak memberikan beban guru dan siswa karena pada dasarnya daring memberikan kemudahan kegiatan belajar mengajar. Kedua, pemberian tugas sewajarnya sesuai tujuan belajar dengan instruksi jelas. Pemberian tugas tersebut didasari komunikasi melalui dialog, 
pemberian stimulus maupun selingan humor. Sedangkan kejelasan instruksi melalui umpan balik (feed back) dan pembimbingan. Ketiga, memanfaatkn sumber belajar melalui media maya. Keempat, tempat dan waktu fleksibel menyesuaikan masing-masing peserta didik. Kelima, keseimbangan guru dan siswa dalam pelaksanaan pembelajaran melalui pengawasan guru dan kesadaran serta kesungguhan siswa dalam melaksanakan pembelajaran.

\section{Keaktifan Siswa}

Asal kata keaktifan adalah aktif dengan imbuhan ke dan an yang didefinisikan kesibukan atau kegiatan. Arti keaktifan disini adalah usaha guru untuk mengaktifkan siswa baik jasmani maupun rohani dalam kegiatan belajar mengajar. Keaktifan jasmani dalam bentuk aktifitas fisik dengan melibatkan gerak badan baik berbentuk kegiatan bekerja maupun bermain. Sementara keaktifan rohani berkaitan dengan jiwa peserta didik yang berfungsi, misalkan mendengar saat menerima penjelasan atau diam saat guru berbicara. Keaktifan jasmani maupun rohani memiliki hubungan dengan pembelajaran Pendidikan Agama Islam (PAI).

Kegiatan belajar merupakan intisari dari keseluruhan proses Pendidikan. Artinya belajar sebagai penentu keberhasilan tujuan Pendidikan, dan wajar sekali bilamana kegiatan belajar bergantung pada proses yang dilakukan siswa. Usaha mencapai keberhasilan pembelajaran, terdapat tuntutan bagi siswa untuk aktif dalam kegiatan tersebut. Beberapa bentuk kegiatan pembelajaran Menurut Paul D. Dierich yang dikutip Hamalik (1990) menyebut aktifitas pembelajaran menjadi 8 bentuk, diantaranya:1) Kegiatan visual, 2) Kegiatan, 3) Kegiatan mendengarkan, 4) Kegiatan menulis, 5) Kegiatan menggambar, 6) Kegiatan metric, 7) Kegiatan mental, 8) Kegiatan emosional. Kedepalan kegiatan tersebut dapat dimaksimalkan melalui kegiatan pembiasan dimana terdapat usaha menyempurnakan atau memperbaiki yang sudah ada (Hidayatullah MF, 2019: 22).

\section{Metode Pembelajaran Penugasan}

Menurut Djamarah (2002 : 95-109), Salah satu metode yang bisa membuat proses belajar menjadi menyenangkan, efektif, dan efisien yaitu metode penugasan. Bentuk penugasan dapat berupa daftar sejumlah pertanyaan terkait mata pelajaran tertentu atau diskusi atas perintah yang diberikan guru untuk menemukan solusi atas permasalahan yang dialami siswa melalui referensi buku pelajaran. Penugasan dapat berbentuk tertulis maupun lisan dengan beberapa metode baik eksperimen maupun observasi.

\section{Umpan Balik (Feedback) dalam Penugasan}

Menurut Unit Pengembangan Pembelajaran Universitas Waikato (2009: 5), siswa menjadi lebih aktif dalam proses pembelajaran bilamana percakapan yang 
disertai umpan balik (feedback) ditingkatkan. Oleh karena itu pentingnya umpan balik dalam pembelajaran untuk memenuhi kegiatan belajar mengajar. Umpan balik meringankan beban siswa dan guru dalam memahami materi pelajaran. Hal ini juga dibenarkan berdasarkan penelitian oleh Nindiah (2012), bahwa pemberian pekerjaan rumah yang disertai umpan balik dapat meningkatkan motivasi dan prestasi belajar siswa. Motivasi dapat tumbuh atas support maupun dorongan seseorang yang menjadi teladan peserta didik agar terdesak bergerak melakukan suatu aktifitas yang diinginkan (Hidayatullah MF, 2018: 66).

\section{Munakahat / Pernikahan}

Sebagaimana dalam agam Islam pernikahan menjadi anjuran bagi umat Islam, salah satu alasannya adalah melalui pernikahan manusia dapat berkembang kehidupannya, karena didalamnya terdapat regenerasi kehidupan umat manusia yang dapat dilestarikan. Allah Swt. mensyariatkan pernikahan dalam firmannya Q.S. an-Nahl/16:72 dengan arti sebagai berikut:

"Allah menjadikan dari kamu istri-istri dari jenis kamu sendiri dan menjadikan bagimu dan istri-istri kamu itu anak-anak dan cucu-cucu dan memberimu rezeki dari yang baik-baik. Maka mengapakah mereka beriman kepada yang bathil dan mengingkari nikmat Allah."

Ayat tersebut mengingatkan manusia tentang pentingnya mengimani rezeki yang diberikan Allah tanpa sedikitpun keraguan melalui jalur pernikahan. Mellaui pernikahan pula Allah Swt. melapangkan rezeki yang baik dan halal untuk hidup berumah tangga,. Kompetensi dasar ini memberikan penjelasan aturan, persyaratan, hokum nikah sesuai aturan agama dan aturan Undang-undang Pernikahan RI (UUPRI) Nomor 1 Tahun 1974, sehingga nantinya seseorang akan mengetahui tujuan Pernikahan.

\section{Kerangka Berfikir}

Rasa keputus asa-an belajar siswa dalam PJJ menyebabkan turunnya keafktifan siswa dalam belajar karena merasa tidak langsung ketemu dengan gurunya, komunikasi yang intens melalui umpan balik pada tugas tugas yang diberikan sebagai bagian dari proses 5M khususnya membangun memanusiakan hubungan dapat mempengaruhi keyakinan siswa tentang pekerjaannya, penilaian tentang kualitas dan dari pengorbanan-pengorbanan yang dilakukan lainnya. Umpan balik yang dikombinasikan dengan strategi belajar penugasan di tengarai efektif untuk meningkatkan keaktifan belajar PAI siswa. Dari pemikiran di atas secara seksama kerangka berfikir dapat divisualisasikan sebagai berikut: 


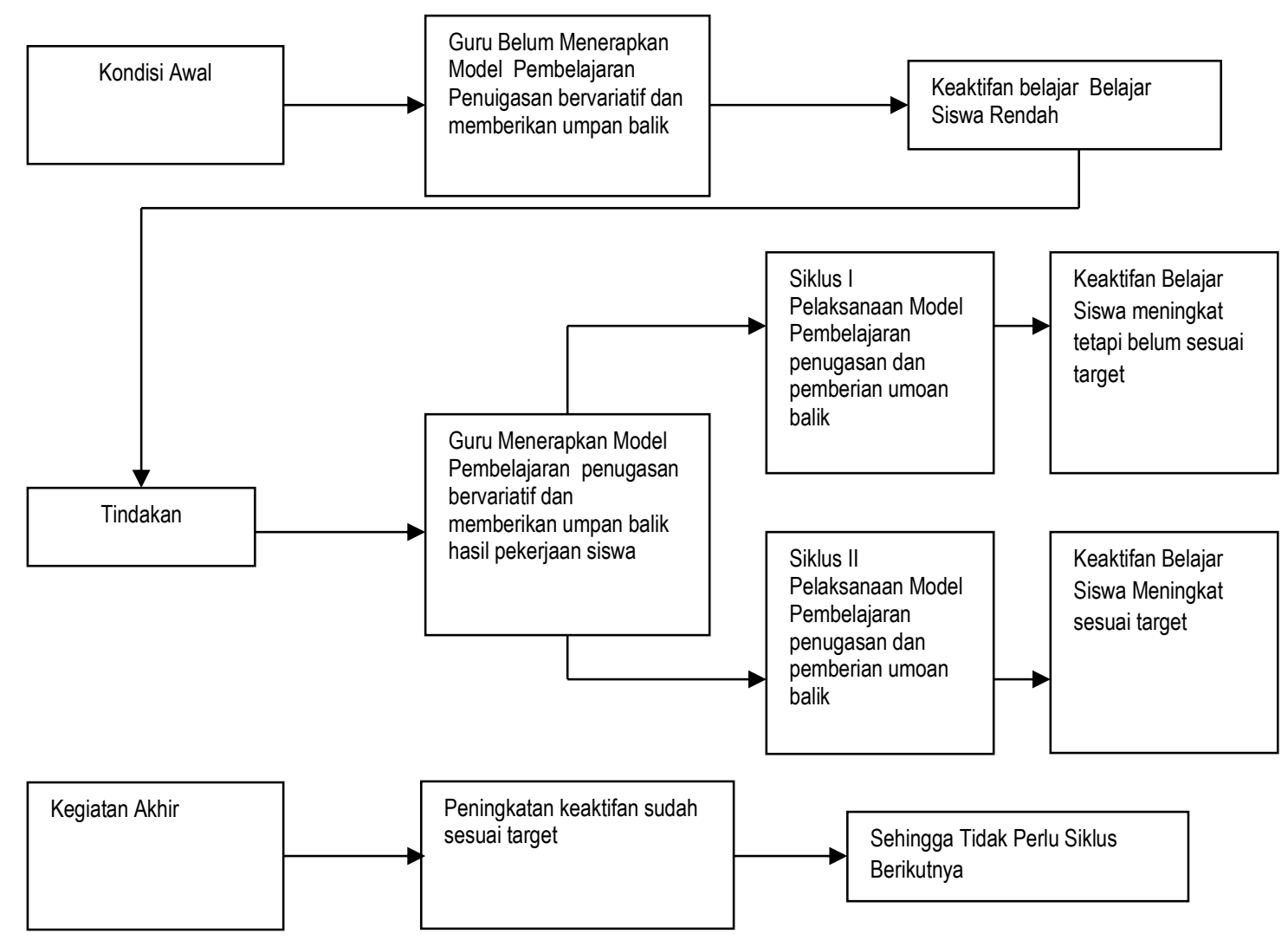

\section{Metode}

Pendekatan yang digunakan dalam penelitian ini adalah kuantitatif deskriptif. Sedangkan jenis penelitiannya adalah penelitian tindakan kelas (PTK), artinya mencari solusi terkait tindakan yang tepat dalam menghadapi masalah atau upaya peningkatan belajar siswa. Adapun obyek penelitiannya adalah siswa kelas XII TPMA SMK Negeri 2 Surakarta, yang terdiri dari 34 siswa. Adapun sumber data penelitian Sumber data primer penelitiuan ini berasal dari subjek penelitian keaktifan belajar siswa, sedangkan data sekunder diperoleh dari hasil pengamatan yang dilakukan oleh kolabolator (teman sejawat), dokumen/arsip dari bagian pengajaran tentang intake siswa, kurikulum, materi pembelajaran, dan rencana pembelajaran.

Teknik yang digunakan untuk mengumpulkan data di atas meliputi teknis tes (pre tes/tes awal dan post tes/tes akhir), observasi, wawancara, catatan lapangan, dan dokumentasi. Tes yang dimaksud disini adalah tes non kognitif yang diberikan kepada siswa dalam bentuk dialog. Teknik analisis datanya melalui pengumpulan data, penyederhanaan data (memilah data penting dan relevan) penyajian data (narasi, visual gambar dan tabel), dan penarikan kesimpulan. Selanjutnya prosedur tindakan dilakukan melalui Siklus dengan jumlah 2 siklus dengan tahapan sebagai 
berikut: 1) penggalian masalah, 2) perencanaan tindakan, 3) pelaksanaan tindakan, 4) pengamatan (observasi), 5) perenungan (refleksi) pada setiap tindakan yang dilakukan, dan 6) pengukuran atau perbaikan kegiatan (evaluasi).

\section{Hasil dan Pembahasan}

\section{Kondisi Awal}

a. Keaktifan belajar siswa

Berdasarkan hasil observasi dan dialog awal dengan guru mitra diperoleh beberapa keterangan atau gambaran bahwa : 1) respon terhadap absensi sejumlah 22 siswa (64\%), 2) komunikasi dalam belajar sejumlah 20 siswa (58\%), 3). respon terhadap tugas yang diberikan guru sejumlah 19 siswa (56\%).

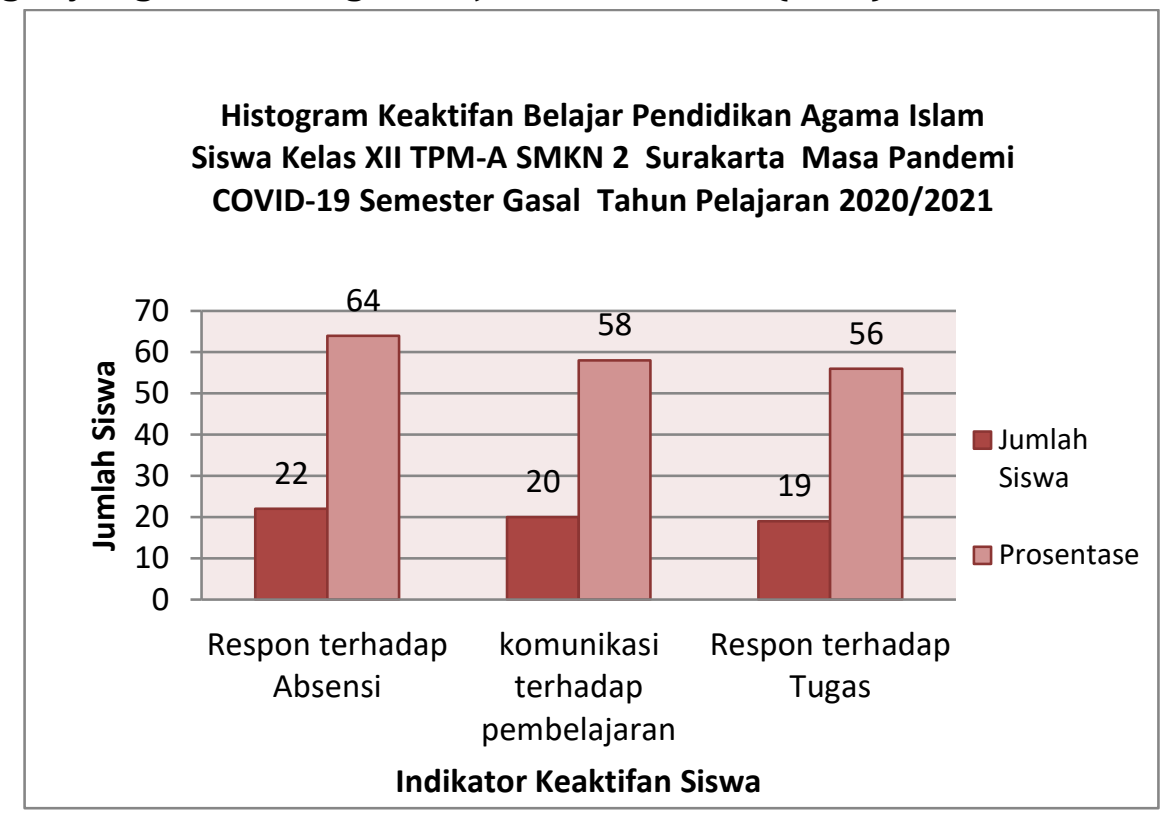

Gambar 2.

Histogram Kondisi Awal Keaktifan Siswa Kelas XII TPM-A dalam Belajar PAI

b. Tindak Mengajar

Penyampaian materi cenderung monoton (metode tidak bervariasi), berpusat pada guru sehingga kurang memotivasi siswa untuk menumbuhkan daya keaktifan siswa dalam bertanya dan mengutarakan idea maupun pertanyaan.Dari hasil kerja kolaborasi antara peneliti dengan teman sejawat, di sepakati bahwa untuk mengatasi masalah pembelajaran yang cenderung satu arah di masa PJJ ini adalah dengan menerapkan metode yang bervariatif yakni metode penugasan bervariatif dan pemberian umpan balik pada penugasan siswa yang telah dikumpulkan. 


\section{Perencanaan Tindakan}

Perencanaan tindakan merupakan semua rencana kegiatan dalam pembelajaran dengan metode penugasan bervariatif dan pemberian umpan balik pada penugasan siswa yang telah dikumpulkan dalam pembelajaran PAI pada materi munakahat atau perkawinan

Agar proses kegiatan tindakan ini dapat berjalan dengan lancar guru peneliti dan teman sejawat terlebih dahulu menyusun silabus yang digunakan sebagai pedoman dalam pembelajaran, sedangkan RPP disusun saat perencanaan tindakan pada masing-masing siklus, dan pengamatan keaktifan pada setiap akhir tindakan.

\section{Pelaksanaan Tindakan}

\section{a. Siklus I}

1) Perencanaan Tindakan

Sebelum melaksanakan tindakan terlebih dahulu menyusun Rencana Pembelajaran. Pembelajaran yang akan dilaksanakan berpedoman pada rencana pembelajaran. Untuk persiapan pra pembelajaran guru mengadakan assessment non kognitif melalui WA group kelas untuk menggali informasi tentang kesiapan siswa dalam pembelajaran daring di google classroom, menanyakan kondisi internet dan menanyakan kondisi keluarga terutama pekerjaan orang tua, hal ini dimaksudkan untuk memantau pembelajaran selama PJJ.

2) Pelaksanaan tindakan siklus I

Tindakan siklus I pertemuan pertama dilaksanakan secara daring (online) sesuai jadwaL pjj, jumlah siswa yang hadir secara tepat waktu sebanyak 24 siswa atau $70 \%$ yang terlambat absen sebanyak 2 siswa atau $6 \%$ dan yang tidak absen sebanyak 6 siswa atau 18\%. Dalam pelaksanaan tindakan, peneliti berperan sekaligus sebagai guru, sedangkan teman sejawat berperan sebagai observer.

3) Hasil tindakan kelas siklus I

a. Tindak Mengajar

Persiapan guru belum cukup matang dilihat dari siswa yang masih kebingungan tentang metode ini. Kemudian guru menerangkan ulang tentang teknis metode penugasan bervariatif dan kelebihannya terhadap keaktifan belajar siswa. Guru melaksanakan cara-cara pemberian penugasan bervariatif yaitu secara online dan offline dalam hal ini offline nya tugas dikerjaklan secara ofline dan online nya melalui video call. Pada kegiatan akhir, guru mengevaluasi pelaksanaan penugasan bervariatif mengamati keaktifan belajar siswa dan memberi motivasi untuk menanyakan materi yang telah di dapatkan di dalam 
penugasan bervariatif dan pemberian umpan balik penugasan. Setelah mengevaluasi dan tanya jawab dilanjutkan penguatan materi oleh guru dan selanjutnya siswa bersama guru menyimpulkan hasil pembelajaran. Sebelum mengakhiri Pembelajaran, guru menyampaikan hasil pengamatan keaktifan belajar siswa. Selanjutnya peneliti memberikan motivasi kepada siswa untuk mempelajari materi berikutnya.

b. Tindak Belajar Siswa

Hasil monitoring terhadap keaktifan belajar siswa dalam Pembelajaran Jarak Jauh sebagai berikut : 1) respon terhadap absensi sejumlah 24 siswa (70\%), 2) komunikasi dalam belajar sejumlah 25 siswa (73,5\%), 3). respon terhadap tugas yang diberikan guru sejumlah 26 siswa (76\%)

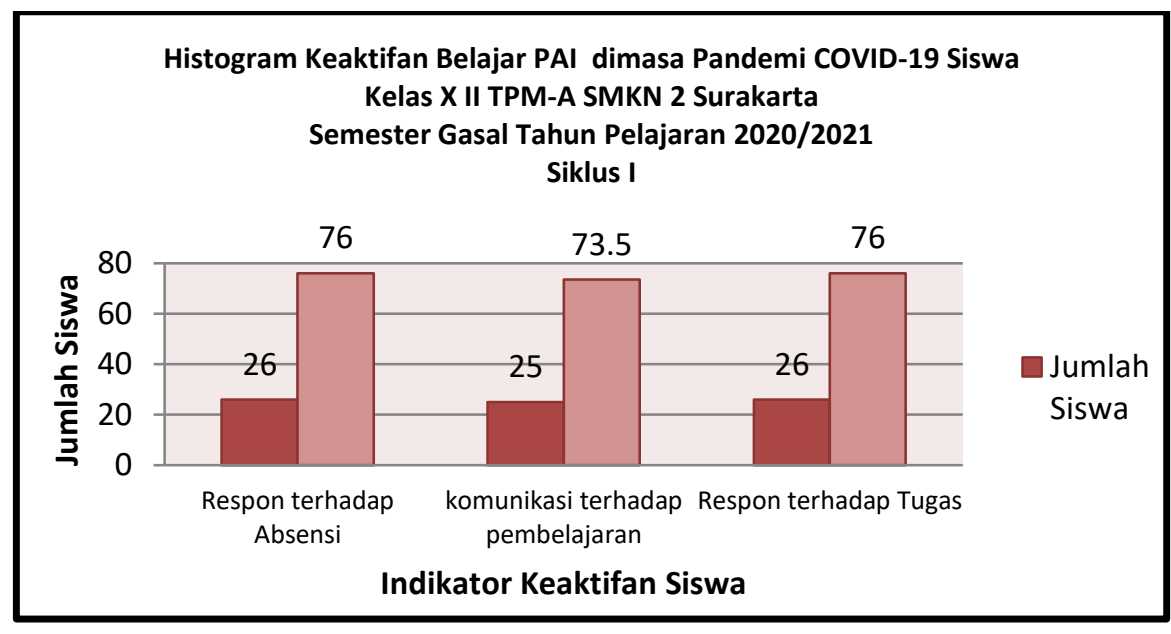

Gambar 3. Histogram Keaktifan Belajar Siswa

Pada Tindakan Kelas Siklus I

4) Refleksi terhadap tindakan kelas siklus I

Kekurangan guru dalam tindak mengajar adalah: Penguasaan materi kurang menyasar, penguasaan kelas kurang merata, bimbingan mengajar tidak merata, menejemen waktu kurang, Penggunaan metode pengajaran kurang optimal, sehingga siswa masih pasif

Adanya beberapa kekurangan dari tindak mengajar tersebut mengakibatkan tindak keaktigan belajar siswa sebagai berikut : keberanian siswa dalam pemunculan gagasan materi masih rendah, keterlibatan siswa dalam kelas pada saat pembelajaran berlangsung masih rendah, pemahaman siswa terhadap materi masih rendah, hal ini terlihat pada kelancaran dalam penyusunan ulang konsep dan perluasan materi kurang jelas, alokasi waktu belum dimanfaatkan secara maksimal. 
5) Evaluasi terhadap tindakan kelas siklus I

Hasil observasi dan refleksi pada tindakan kelas siklus I dievaluasi peneliti dengan guru teman sejawat. Evaluasi ini, diharapkan dapat mengatasi kekurangan dan permasalahan yang terdapat pada siklus I. Hasil evaluasi tersebut adalah: guru harus lebih sering melakukan komunikasi untuk memotivasi dan membimbing siswa agar siswa lebih aktif lagi, menciptakan kondisi belajar jarak Jauh yang terstruktur dan tertata, alokasi waktu penugasan yang direncanakan harus di jadwalkan secara efektif, dan hasil keaktifan belajar siswa belum sesuai yang diharapkan.

\section{b. Siklus II}

1) Perencanaan tindakan kelas siklus II

Berdasarkan hasil pada evaluasi kelas pada siklus I, maka ada beberapa yang harus di perbaiki dan perubahan tersebut dirangkum dalam pelaksanaan tindakan kelas siklus II.

2) Pelaksanaan tindakan kelas siklus II

Pelaksanaan siklus II terdiri dari dua kali pertemuan, kegiatan tersebut di rangkum sebagai berikut : pada kegiatan awal setelah guru memasuki dasboard Google Classroom guru membuka percakapan di forum kelas dengan mengucapkan salam, membuat daftar absen siswa dan guru memberi motivasi, memberi pengarahan mengenai tujuan dan prosedur pembelajaran. Tindakan selanjutnya guru memposting materi berupa modul materi ajar yaitu pernikahan menurut Undang-Undang Perkawinan Indonesia No. 1 Tahun 1974. Setiap siswa diberikan waktu untuk mempelajari materi selanjutnya mengerjakan tugas membuat makalah tentang nikah beda agama. Langkah berikutnya setiap siswa diminta berdiskusi dengan sumber belajar di rumah atau lingkungan rumah membahas tentang nikah beda agama, yang selanjutnya dituangkan dalam makalah yang nanti akan dipresentasikan melalui video call. Setelah itu dilanjutkan penguatan materi dan menarik kesimpulan dari materi tentang pentingnya Undang Undang perkawinan di Indonesia, selanjutnya sebelum mengakhiri pembelajaran guru memberi tahu materi selanjutnya yaitu hak dan kewajiban suami istri, dan memberikan umpan balik kepada siswa, tentang perasaan belajar dengan penugasan bervariatif ini, dan meminta alasan kepada siswa tentang perasaan belajar melalui penugasan ini.

3) Hasil tindakan kelas siklus II

a. Observasi dan monitoring tindakan kelas siklus II

Hasil monitoring terhadap keaktifan belajar siswa terlihat bahwa : 1) respon terhadap absensi sejumlah 32 siswa (94\%), 2) komunikasi dalam belajar 
sejumlah 30 siswa (88\%), 3). respon terhadap tugas yang diberikan guru sejumlah 31 siswa (91\%).

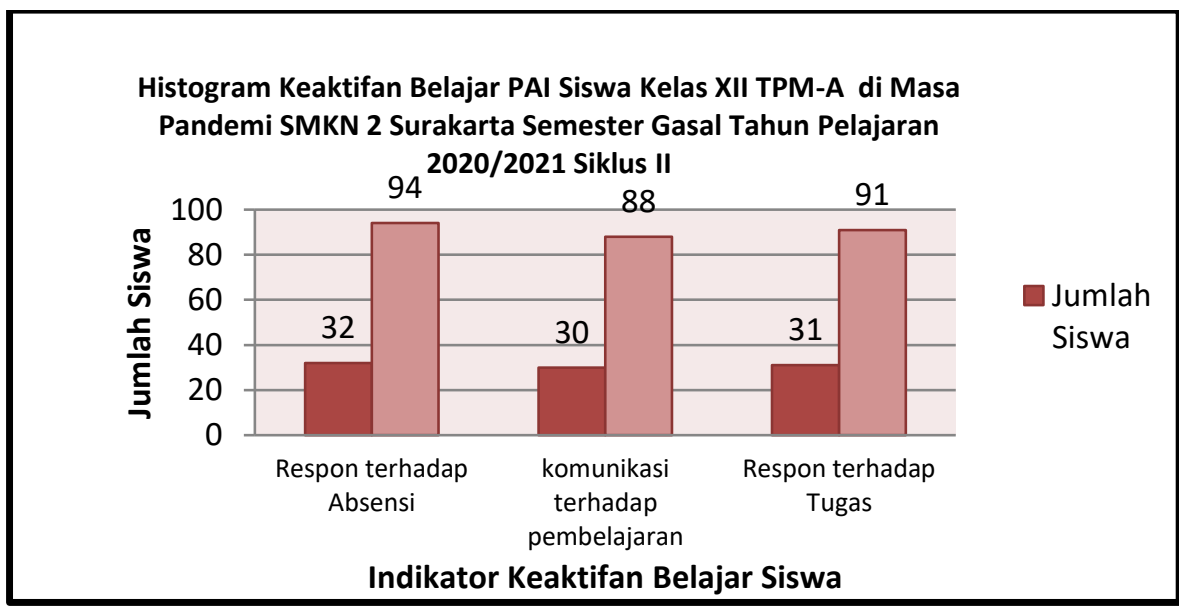

Gambar 4.

Histogram Keaktifan Belajar Siswa

Pada Tindakan Kelas Siklus II

4) Refleksi terhadap tindakan kelas siklus II

Kegiatan refleksi ini didapatkan hasil sebagai berikut : pembelajaran Jarak Jauh pada tindakan kelas siklus II mengalami banyak peningkatan dibandingkan pada siklus I, keaktifan siswa dalam belajar, penugasan yang diberikan telah mengalami peningkatan sehingga siswa lebih matang dalam bertukar informasi harapannya pengalaman bermaknya tinggi, pemusatan keaktifan dan komunikasi siswa cukup optimal, penerapan penugasan bervariatif dan pemberian umpan balik memberikan manfaat terutama peningkatan keaktifan belajar siswa.

5) Evaluasi terhadap tindakan kelas siklus II

Hasil observasi dan refleksi pada tindakan kelas siklus II hasil sebagai berikut : keaktifan siswa dalam pembelajaran mengalami peningkatan yang sangat baik, siswa sudah menggunakan narasumber lain dalam bertukar informasi materi maupun dalam memperdalam materinya, dengan menempuh metode pembelajaran penugasan dan pemberian umpan balik melalui daring secara benar dan optimal, seluruh siswa aktif melibatkan diri dan meningkat elajarnya.

\section{Temuan Tindakan}

Hasil tindakan kelas siklus I sampai II yang telah dilakukan, hasilnya mengalami perubahan yang positif, yaitu meningkatnya keaktifan belajar siswa dalam pembelajaran PAI pada materi munakahat atau perkawinan yang disajikan Andragogi: Volume 2 Nomor 2, 2020 
dengan membandingkan keaktifan belajar yang dicapai siswa. Data hasil keaktifan belajar siswa sesuai indikator-indikator yang di gunakan untuk mengamati tingkat keaktifan siswa adalah : 1) respon terhadap absensi 2) komunikasi dalam belajar, 3). respon terhadap tugas yang diberikan guru. Adapun perubahannya di sajikan tabel sebagai berikut :

Tabel 1

Data Hasil Peningkatan Keaktifan Belajar PAI

Siswa Kelas XII TPM-A Di Masa Pandemi COVID-19

SMKN 2 Surakarta Semester GasalTahun Pelajaran 2020/2021

\begin{tabular}{|c|c|c|c|c|c|c|}
\hline \multirow[b]{2}{*}{ Indikator Keaktifan } & \multicolumn{2}{|c|}{ Kondisi Awal } & \multicolumn{2}{|c|}{ Siklus I } & \multicolumn{2}{|c|}{ Siklus II } \\
\hline & $\begin{array}{l}\text { Jumlah } \\
\text { siswa } \\
\text { yang } \\
\text { aktif }\end{array}$ & $\begin{array}{c}\text { Prosen } \\
\text { tase }\end{array}$ & $\begin{array}{l}\text { Jumlah } \\
\text { siswa } \\
\text { yang } \\
\text { aktif }\end{array}$ & $\begin{array}{c}\text { Prosen } \\
\text { tase }\end{array}$ & $\begin{array}{l}\text { Jumlah } \\
\text { siswa } \\
\text { yang } \\
\text { aktif }\end{array}$ & $\begin{array}{c}\text { Prosen } \\
\text { tase }\end{array}$ \\
\hline $\begin{array}{l}\text { 1. Siswa yang merepon } \\
\text { absen } \\
\text { a. Secara tepat waktu } \\
\text { b. Terlambat } \\
\text { c. Tidak absen }\end{array}$ & $\begin{array}{c}22 \\
4 \\
8\end{array}$ & $\begin{array}{l}64 \% \\
12 \% \\
24 \%\end{array}$ & $\begin{array}{r}26 \\
4 \\
4\end{array}$ & $\begin{array}{l}76 \% \\
12 \% \\
12 \%\end{array}$ & $\begin{array}{r}32 \\
2 \\
0\end{array}$ & $\begin{array}{r}94 \% \\
6 \% \\
0 \%\end{array}$ \\
\hline $\begin{array}{l}\text { 2. siswa yang } \\
\text { berkomunikasi dengan } \\
\text { guru terhadap pelajaran }\end{array}$ & 20 & $58 \%$ & 25 & $73.5 \%$ & 30 & $88 \%$ \\
\hline $\begin{array}{l}\text { 3. siswa yang merespon } \\
\text { tugas }\end{array}$ & 19 & $56 \%$ & 26 & $76 \%$ & 31 & $91 \%$ \\
\hline
\end{tabular}

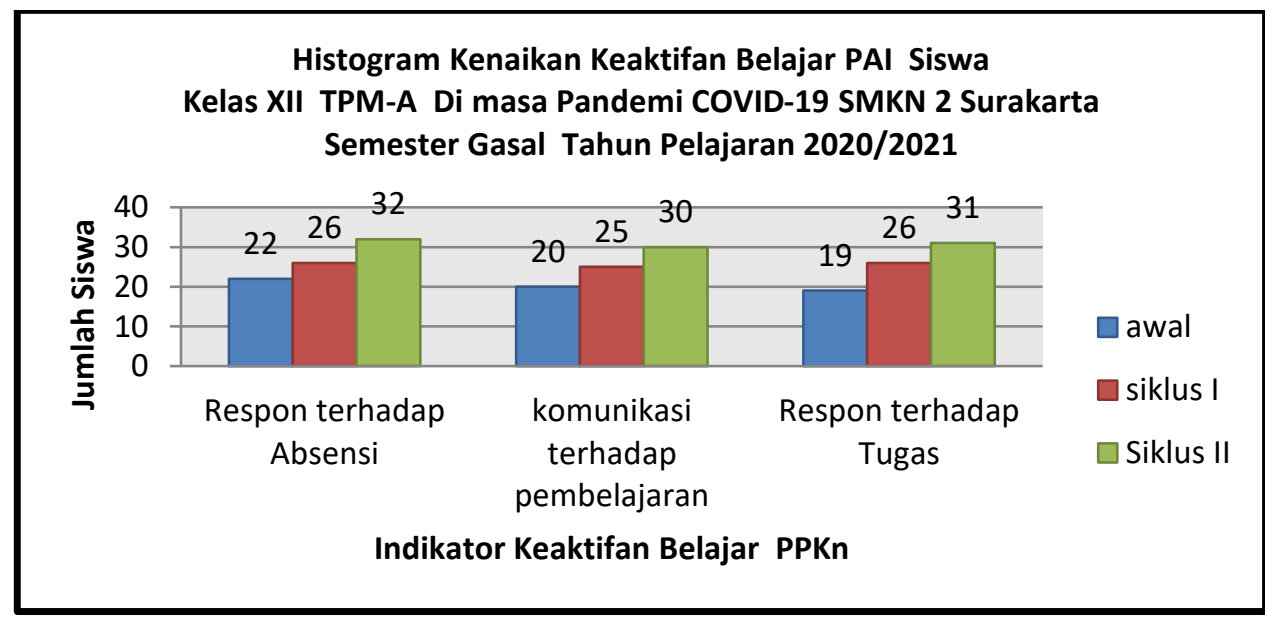

Gambar 5.

Histogram Peningkatan Keaktifan Belajar PAI Siswa Kelas XII- TPM-A di Masa Pandemi Covid-19 SMKN 2 Surakarta Semester Gasal Tahun Pelajaran 2020/2021 selama Tindakan 
Tingginya keaktifan belajar siswa setelah diterapkannya metode pembelajaran penugasan bervariatif dan pemberian umpan balik karena pada proses pembelajaran siswa tidak lagi dijadikan objek melainkan siswa menjadi pusat pembelajaran. Dari proses pembelajaran tersebut siswa mendapatkan pengalaman belajar yang bermakna sesuai dengan kajian ilmu pengetahuan yang dipelajarinya secara optimal. Pada pembelajaran penugasan bervariatif dan pemberian umpan balik, siswa dituntut menjadi ahli dengan cara mengungkapkan pendapatnya secara bergilir melalui video call, tidak malu atau takut untuk menyampaikan materi dan ide atau gagasan, saling meningkatkan keterampilan dalam berkomunikasi, dan meningkatkan aktivitas dan kreativitas siswa. Ini sesuai dengan yang dikemukakan oleh Melvin L. Silberman (2007), yaitu ketika pembelajaran itu aktif apabila melakukan aktivitas, mereka menggunakan potensi otak untuk mengkaji ide-ide, memecahkan masalah dan menerapkan apa yang mereka pelajari.

\section{Simpulan}

Penerapan metode pembelajaran penugasan bervariatif dan pemberian umpan balik pada mata pelajaran PAI dapat meningkatkan keaktifan belajar siswa kelas XII TPM-A SMKN2 Surakarta Semester Ganjil 2020/2021 di masa Pandemi. Hal ini dibuktikan dengan indikator keaktifan siswa melalui presentase komunikasi siswa dengan guru terhadap pelajaran sebelum metode diterapkan berjumlah $58 \%$. Sedangkan siklus I sebagai tahap awal metode diterapkan dengan mengawali komunikasi guru dengan siswa melalui WA group tentang penggalian informasi kesiapan belajar siswa dengan menggunakan daring yang dilanjutkan penerapan metode. Hasil komunikasi siswa dengan guru pada mata pelajaran berjumlah $73,5 \%$. Sedangkan pada siklus II melalui perbaikan kekurangan salah satunya kesaiapan guru belum cukup matang diawali dengan percakapan guru dan siswa melalui Google Classroom didpatkan hasil 88\% komunikasi guru dengan siswa terhadap materi pelajaran.

\section{Daftar Rujukan}

Bakri, M., \& Werdaningsih, D. (2017). Membumikan Nilai Karakter Berbasis Pesantren, Belajar dari Best Practice Pendidikan Karakter Pesantren dan Kitab Kuning. Cet. II. Jakarta: Nirmana MEDIA.

Djamarah Syaiful Bahri. 2002. Strategi Belajar Mengajar. Jakarta : Rineka Cipta.

Hamalik O. 1990. Proses Belajar Mengajar. Jakarta: Bumi Aksara.

Hidayatullah, Muhammad Fahmi. 2018. Paradigma Pendidikan Keluarga: Supervisi Andragogi: Volume 2 Nomor 2, 2020 
dan Motiv Keterlibatan Oran Tua....Jurnal Tarbiyatuna Volume 2 Nomor 1.

Hidayatullah, Muhammad Fahmi. 2019. Model Pendidikan Karakter Sepenuh Hati Pada Siswa Madrasah Ibtidaiyah, Jurnal Elementeris, Volume 1 Nomor 2.

Moedjiono D, 1993. Strategi Belajar Mengajar, Jakarta: Departemen. Pendidikan dan Kebudayaan.

Nindiah. 2012. Meningkatkan Motivasi dan Prestasi Belajar Matematika Melalui Pemberian Pekerjaan Rumah Disertai Umpan Balik pada Siswa Kelas VIII A SMP Negeri 1 Tujuh Belas. Skripsi (Tidak Diterbitkan). Pontianak: FKIP Universitas Tanjungpura

Permendikbud. nomor 72 Tahun 2013

Roestiyah NK1991.., Strategi Belajar Mengajar, Jakarta: Rineka Cipta.

Safi'i, Imam. 2017. Pendidikan Agama di Lingkungan Keluarga Guna Membangun Mentalitas Bangsa. Vicratina, Volume 2 Nomor 2.

SKB Mendikbud, Menteri Agama, Menteri Kesehatan, Dan Menteri Dalam Negeri Tentang Perubahan Atas Keputusan Bersama Menteri Pendidikan Dan Kebudayaan, Menteri Agama, Menteri Kesehatan, Dan Menteri Dalam Negeri Nomor $01 / \mathrm{Kb} / 2020$, Nomor 516 Tahun 2020, Nomor Hk.03.01/Menkes/363/2020, Nomor 440-882 Tahun 2020 Tentang Panduan Penyelenggaraan Pembelajaran Pada Tahun Ajaran 2020/2021 Dan Tahun Akademik 2020/2021 Di Masa Pandemi Corona Virus Disease 2019 (Covid19).

Sukmadinata. 2002. Metode Penelitian Pendidikan. Bandung: Remaja Rosda.

Teaching Development Unit. 2009. Assessment: Feedback to Promote Student Learning. New Zealand: The University of Waikato 